\title{
PENGARUH PEMBERIAN PAKAN PENGISI PADA AYAM BROILER UMUR 22-28 HARI TERHADAP PERTUMBUHAN, DAN KANDUNGAN LEMAK KARKAS DAN DAGING
}

\section{THE EFFECT OF STUFF FEEDING DURING 22-28 DAYS OF AGES ON GROWTH AND PERCENTAGE OF MEAT AND ABDOMINAL FAT PAD OF BROILER}

\author{
Tri Rumiyani ${ }^{1 *}$, Wihandoyo ${ }^{2}$, dan Jafendi Hasoloan Purba Sidadolog ${ }^{2}$ \\ ${ }^{1}$ Fakultas Pertanian, Universitas Gunung Kidul, Jl. K.H. Agus Salim No. 170, Wonosari, Yogyakarta \\ ${ }^{2}$ Fakultas Peternakan, Univesitas Gadjah Mada, Jl. Fauna No. 3, Bulaksumur, Yogyakarta, 55281
}

\section{INTISARI}

Penelitian ini bertujuan untuk mengetahui pengaruh pemberian pakan pengisi dengan bahan yang rendah nutrien dan berserat yang diberikan selama 7 hari dari umur 22 sampai dengan 28 hari terhadap kinerja pertumbuhan dan kadar lemak daging ayam broiler. Sebanyak 180 ekor ayam yang terdiri dari 90 ekor jantan (J) dan 90 ekor betina (B) masingmasing dibagi menjadi 6 kelompok perlakuan dengan 3 kali ulangan dan tiap ulangan terdiri dari 10 ekor ayam. Pada umur 1-21 hari semua ayam diberi pakan Starter Broiler (SB), pada umur 22-28 hari baik jantan dan betina diberi pakan Starter Broiler (K), dedak jagung (DJ) dan pollard (P) dan untuk kelompok DJ dan P ditambah mineral B-12. Pada umur 29-42 hari semua kelompok kembali diberi pakan SB. Data yang dikumpulkan adalah berat badan, konsumsi pakan, konversi pakan, berat karkas, lemak perut, dan lemak daging. Data dianalisis menggunakan analisis variansi RAL pola split-plot ( 3 perlakuan pakan, 2 jenis kelamin dan 3 fase) dan dilanjutkan dengan uji DMRT untuk uji beda antar perlakuan. Hasil penelitian pemberian pakan $\mathrm{K}$, DJ, dan $\mathrm{P}$ menunjukkan perbedaan nyata $(\mathrm{P}<0,05)$ pada berat badan (1583, 1289, dan $1213 \mathrm{~g}$ ), konsumsi pakan $(1180,1051$, dan $1035 \mathrm{~g})$, konversi pakan $(1,67,2,62$, dan -1,89), persen lemak perut $(1,80,2,03$, dan $1,29 \%)$. Perlakuan $\mathrm{J}$ dan $\mathrm{B}$ terdapat perbedaan nyata $(\mathrm{P}<0,05)$ pada berat badan dan persen lemak perut. Pada perlakuan fase menunjukkan perbedaan yang nyata $(\mathrm{P}<0,05)$ pada berat badan, konsumsi pakan, persen karkas, dan kadar lemak daging. Interaksi perlakuan jenis kelamin dan pakan menunjukkan perbedaan nyata $(\mathrm{P}<0,05)$ pada lemak daging umur 22 hari. Interaksi perlakuan pakan, jenis kelamin dan fase menunjukkan perbedaan nyata $(\mathrm{P}<0,05)$ pada berat badan dan konsumsi pakan. Dari penelitian ini dapat disimpulkan bahwa, pemberian pakan pengisi menurunkan berat badan, konsumsi, persen lemak perut, dan sebaliknya menaikkan konversi pakan, serta lemak daging.

(Kata kunci: Ayam broiler, Jenis kelamin, Pakan pengisi, Starter Broiler, Dedak jagung, Pollard)

\section{ABSTRACT}

The experiment was conducted to study the effect of stuff feeding given during 22 to 28 days of ages on growth, meat fat and abdominal fat of broiler. Ninety broiler males $(J)$ and 90 broiler females $(B)$ were divided into 6 treatments groups with 3 replications of 10 broiler chickens each. The treatment were control $(K)$ chicken which was fed with commercial diets from DOC to 42 days of age, DJ and $P$ chickens were fed with corn bran (DJ) or pollard $(P)$ from 22 to 28 days and continued with commercial feeding until 42 days. Feeds for DJ and $P$ treatment was supplemented with B-12 mineral. Data collected were body weight, feed consumption, feed conversion, carcass weight, meat as well as abdominal fat. The data were analyzed by analysis split-plot design ( 3 feed treatments, 2 sex treatments and 3 phases) and then were tested by DMRT. The results showed that the feed treatments $(K, D J$, and $P)$ significantly affected $(P<0.05)$ the body weight $(1583,1289$, and $1213 \mathrm{~g})$, feed consumption (1180, 1051, and $1035 \mathrm{~g})$, feed conversion (1.67; 2.62; and -1.89), percentage of abdominal fat (1.80, 2.03, and 1.29\%). Sex (J and B) significantly influenced $(P<0.05)$ on body weight, feed conversion, percentage of abdominal fat, but feed consumption, percentage of carcass, meat fat, had no significant differences. The interaction of sex and feed showed significant influence $(P<0.05)$ on meat fat at 22 day of ages. The interaction of feed, sex, and phase had significant influence $(P<0.05)$ on body weight and feed consumption. It could be concluded that stuff feeding decreased body weight, feed consumption, percentage of abdominal fat, but increased feed conversion and meat fat.

(Key words: Broiler chicken, Sex, Feed stuff, Broiler Starter, Corn bran, Pollard)

\footnotetext{
*Korespondensi (corresponding author):

Telp. +62 81556471399

E-mail: Annniqs3@yahoo.com
} 


\section{Pendahuluan}

Pemenuhan kebutuhan protein hewani masyarakat Indonesia masih banyak tergantung dari produk peternakan terutama adalah dari ternak ayam. Daging ayam broiler merupakan produk peternakan yang banyak menyumbangkan dalam pemenuhan kebutuhan daging. Ternak unggas di Indonesia sebagai penghasil daging menduduki peringkat tertinggi (53\%) dari total produksi daging tahun 1993 (Zuprizal, 2006). Problem dari daging ayam broiler ini adalah tingginya kadar lemak (16\%) dalam daging. Hal ini menyebabkan konsumen yang mempunyai persoalan dengan penyakit kolesterol akan memilih produk ayam broiler yang rendah kandungan lemaknya.

Pemeliharaan ayam broiler yang baik selain menghasilkan produk yang aman untuk dikonsumsi juga dapat menurunkan biaya produksi. Ayam broiler mempunyai laju pertumbuhan yang cepat dan perlemakan terjadi mulai pada umur 4 minggu sehingga pada umur 6 minggu kandungan lemak daging adalah 10,3\% sampai 15,8\% (Hunton, 1995). Untuk mengurangi kandungan lemak ayam broiler telah dilakukan oleh beberapa peneliti diantaranya adalah pemberiaan tepung bulu dengan persentase yang semakin tinggi akan menurunkan persentase lemak abdominal yaitu pada pemberian 7,5\% tepung bulu menurunkan lemak abdominal dari $2,02 \%$ menjadi $1,56 \%$ (Nuraini et al., 2002). Komposisi larutan jamu yang terdiri dari $1,0 \mathrm{~kg}$ kencur, $1,0 \mathrm{~kg}$ bawang putih, $0,5 \mathrm{~kg}$ jahe, $0,5 \mathrm{~kg}$ lengkuas, $0,5 \mathrm{~kg}$ kunyit, $0,5 \mathrm{~kg}$ temulawak, $0,25 \mathrm{~kg}$ daun sirih dan $0,25 \mathrm{~kg}$ kulit kayu manis yang diberikan pada air minum ayam dapat menurunkan lemak daging dada ayam buras dari $0,5 \%$ menjadi kurang dari $0,025 \%$ atau berkisar antara $0-0,1 \%$ (Anonimus, 2004). Penambahan pakan yang mengandung serat tinggi yaitu khitin $100 \%$ dapat menurunkan persentase lemak daging ayam broiler (Supadmo, 1997).

Pemberian pakan dengan kandungan serat tinggi ternyata dapat menurunkan kandungan lemak karkas. Manipulasi pakan secara spesifik dapat dilakukan dengan dua pendekatan salah satunya adalah pendekatan sistem gastrointestinal yaitu berusaha agar lemak dan kolesterol yang ada pada tubuh ayam dapat dikeluarkan melalui ekskreta. Mekanisme aksi dari keberadaan serat dalam saluran pencernaan ayam adalah mengikat sebagian garam empedu untuk dikeluarkan lewat ekskreta, karena sebagian besar garam empedu dikeluarkan, maka tubuh perlu mensintesis garam empedu yang berasal dari kolesterol tubuh sehingga kolesterol tubuh dapat berkurang (Supadmo, 1997). Penggunaan khitin sebagai sumber serat untuk unggas masih belum lazim digunakan karena ketersediaan- nya terbatas dan sulit dicari peternak, untuk itu perlu dicari teknis menurunkan kandungan lemak karkas ayam broiler yang murah dan mudah dikerjakan oleh peternak yaitu dengan memberikan pakan pengisi dari bahan yang mempunyai kandungan serat tinggi yaitu pollard dengan kandungan serat kasar 7,67\% (Palupi, 2003) dan dedak jagung dengan kandungan serat kasar sebesar $10,0 \%$ (Suparjo et al., 2003) pemberian pakan pengisi pada saat ayam mulai melakukan penimbunan lemak (4 minggu) dan diberikan selama waktu tertentu. Teknis ini diharapkan mampu menurunkan kadar lemak karkas ayam broiler.

Haryadi dan Wihandoyo (2005) melaporkan bahwa pemberian pakan pengisi selama 7 hari diperoleh bobot badan dan pendapatan yang menyamai kontrol, bobot badan kontrol 2.125,67 g/ekor sedangkan pada pemberian pakan pengisi adalah 1.820,07 g/ekor. Penurunan berat badan akibat pemberian pakan pengisi selama waktu tertentu dapat diperbaiki dengan memberikan pakan serasi, setelah selesai pemberian pakan pengisi dengan pakan serasi karena ayam dapat memanfaatkan phenomena compensatory growth seperti dilaporkan oleh Soeparno (1994). Compensatory growth yaitu pertumbuhan kembali dengan cepat bahkan lebih cepat dari pertumbuhan normalnya setelah ternak kekurangan gizi dan mengalami pertumbuhan lambat.

Dalam penelitian ini dicoba memberi pakan dengan bahan kadar nutrien rendah (serat tinggi) pada ayam broiler selama satu minggu dari umur 22-28 hari setelah itu diberi pakan serasi sampai umur 42 hari, selanjutnya diteliti pertumbuhan karkas dan lemak perut.

\section{Materi dan Metode}

Penelitian ini telah dilaksanakan di kandang unggas Fakultas Peternakan Universitas Gadjah Mada Yogyakarta dan di Pusat Antar Universitas (PAU) pangan dan gizi Universitas Gadjah Mada selama kurang lebih 3 bulan.

\section{Alat penelitian}

Peralatan yang digunakan dalam penelitian adalah kandang koloni yang dilengkapi dengan alat makan dan minum. Timbangan yang digunakan adalah timbangan kapasitas $5 \mathrm{~kg}$ dengan kepekaan 20 g, Neraca Ohaus kapasitas $20 \mathrm{~kg}$ dengan kepekaan $1 \mathrm{~g}$ dan timbangan digital kapasitas $1,2 \mathrm{~kg}$ dengan kepekaan $0,1 \mathrm{~g}$.

\section{Materi penelitian}

Penelitian ini menggunakan ayam broiler strain "Lohman" umur 1 hari sebanyak 180 ekor yang terdiri dari 90 ekor jantan dan 90 ekor betina. 
Pakan yang digunakan adalah pakan komersial dan pakan pengisi yang terdiri dari dedak jagung dan pollard yang ditambah mineral B-12 dengan kandungan nutrien bahan pakan seperti tersaji pada Tabel 1.

\section{Metode penelitian}

Ayam broiler umur 1 hari terdiri dari 90 ekor ayam jantan dan 90 ekor ayam betina yang masingmasing ayam dibagi menjadi 6 kelompok perlakuan dengan 3 kali ulangan dan tiap ulangan terdiri dari 10 ekor ayam, sehingga ayam terbagi kedalam 18 kandang kelompok. Pada umur 1-21 hari semua perlakuan diberi pakan komersial berupa pakan Starter Broiler (SB). Umur 22-28 hari, kelompok kontrol (K) diberi pakan SB, kelompok dedak jagung (DJ) diberi pakan dedak jagung ditambah mineral B-12 sebanyak 2\%/kg pakan dan kelompok pollard (P) diberi pakan pollard dan mineral B-12 sebanyak 2\%/kg pakan. Pada umur 29-42 hari kembali diberi pakan komersial (SB).

Pada umur 22, 29 dan 42 hari diambil sampel feses untuk analisis kandungan lemak dan serat kasar. Pada umur yang sama juga dilakukan pemotongan ayam masing-masing 2 ekor setiap ulangan yang mempunyai bobot sama atau mendekati rerata bobot populasi dalam satu ulangan. Pemotongan digunakan untuk mengukur karkas, lemak perut, berat dan panjang tulang femur. Dari karkas akan diambil sampel daging dada dan paha kanan kiri untuk analisis kandungan lemak daging.

Data yang dikumpulkan meliputi berat badan, konsumsi pakan, konversi pakan, persen karkas, lemak perut, dan kandungan lemak daging. Berat badan ayam ditimbang setiap 7 hari sekali dari DOC sampai dengan umur 42 hari dengan satuan g/ekor/minggu. Konsumsi pakan dihitung dengan cara menimbang pakan yang diberikan selama 7 hari dikurangi dengan sisa pakan selama 7 hari. Konversi penggunaan pakan dihitung dengan cara menghitung konsumsi pakan tiap ekor tiap minggu kemudian dibagi dengan pertambahan bobot badan perminggu.

Karkas adalah berat tubuh ayam setelah dipotong dikurangi darah, bulu, leher, kepala, dan organ dalam kecuali paru-paru dan ginjal (Soeparno, 1994). Persentase karkas adalah persentase berat karkas dari berat hidup. Lemak perut diambil dari bagian rongga perut ayam dan yang menempel pada organ-organ dalam ayam kemudian menimbang beratnya. Kandungan lemak daging diambil sampel daging bagian paha kanan dan kiri, serta bagian dada sebanyak 30 gram pada tiap tempat kemudian di campur dan dianalisis dengaan analisis proksimat dengan cara ekstraksi (Sudarmadji et al., 1989).

\section{Analisis data}

Data yang diperoleh dianalisis dengan menggunakan analisis variansi Rancangan Acak Lengkap pola split-plot dan akan dilanjutkan dengan uji Duncan's New Multiple Range Test (Steel dan Torrie, 1993) untuk uji beda antar perlakuan.

\section{Hasil dan Pembahasan}

\section{Konsumsi pakan}

Analisis statistik konsumsi pakan ayam interaksi perlakuan pakan, jenis kelamin, dan fase menunjukkan perbedaan yang nyata $(\mathrm{P}<0,05)$. Pada fase awal konsumsi jantan dan betina menunjukkan jumlah konsumsi pakan yang sama, kemudian pada fase tengah menunjukkan konsumsi pakan yang berbeda karena pada fase ini pakan yang diberikan berbeda, kemudian pada fase akhir konsumsi pakan pakan yang berbeda. Interaksi antara perlakuan pakan dan jenis kelamin menunjukkan perbedaan yang tidak nyata. Pada perlakuan pakan jantan dan betina pada pakan K, DJ, dan P jumlah pakan yang dikonsumsi sama. Hal ini menarik sekali karena pakan $\mathrm{P}$ yang mula-mula mengkonsumsi pakan

Tabel 1. Kandungan nutrien bahan pakan (nutrient content of feed ingredient)

\begin{tabular}{llcccccc}
\hline \hline No & \multicolumn{1}{c}{ Nama (name) } & $\mathrm{CP}(\%)^{1}$ & $\mathrm{Ca}(\%)^{1}$ & $\mathrm{P}(\%)^{1}$ & $\mathrm{LK}(\%)^{1}$ & $\mathrm{SK}(\%)^{1}$ & $\begin{array}{c}\text { ME } \\
(\mathrm{kcal} / \mathrm{kg})^{1,4}\end{array}$ \\
\hline 1 & Starter broiler (starter broiler) $^{1,4}$ & $21-23$ & $0,9-1,1$ & $0,7-0,8$ & $4-8$ & $3-5$ & $2.900-3.100$ \\
2 & Dedak jagung (corn bran) $^{3}$ & 10,36 & - & - & 11,24 & 4,35 & $3.341,10^{3}$ \\
3 & Pollard $^{3}$ & 15,52 & - & - & 2,91 & 9,08 & $2.341,52^{3}$ \\
4 & Mineral B-12 $^{2}$ & - & 50 & 15 & - & - & - \\
\hline
\end{tabular}

CP: protein kasar (crude protein), Ca: kalsium (calcium), P: pospor (phosphorus), LK: lemak kasar (extract ether), SK: serat kasar (crude fiber), ME: energi termetabolisme (metabolizable energy).

2 Berdasarkan label kemasan (based on packing label).

3 Berdasarkan hasil analisis laboratorium Biokimia PAU UGM (2007) (base on laboratory analysis at biochemistry laboratory of PAU UGM (2007)).

4 Estimasi ME dedak jagung dan pollard menurut rumus Jansen et.al. (1979) cit. NRC (1994) (ME estimation of corn bran and pollard according to Jansen et al. (1979) cit. NRC (1994)). 
Tabel 2. Konsumsi pakan (g/ekor) ayam pada setiap fase umur (feed consumption (g/head) of chicken at every age phase)

\begin{tabular}{|c|c|c|c|c|}
\hline \multirow{2}{*}{ Jenis kelamin $(s e x)$} & \multirow{2}{*}{ Fase $(\text { phase })^{1}$} & \multicolumn{3}{|c|}{ Pakan $(\text { feed })^{2}$} \\
\hline & & $\mathrm{K}$ & DJ & $\mathrm{P}$ \\
\hline \multirow[t]{4}{*}{ Jantan (male) } & 1 & $569,83^{b}$ & $561,09^{b}$ & $577,83^{\mathrm{b}}$ \\
\hline & 2 & $852,59^{\mathrm{c}}$ & $616,73^{\mathrm{b}}$ & $447,50^{\mathrm{a}}$ \\
\hline & 3 & $2.078,55^{\mathrm{e}}$ & $2.048,26^{\mathrm{e}}$ & $2.096,53^{\mathrm{e}}$ \\
\hline & Rerata (average) ${ }^{\text {ns }}$ & $1.167,32$ & $1.075,35$ & $1.040,62$ \\
\hline \multirow[t]{4}{*}{ Betina (female) } & 1 & $588,94^{\mathrm{b}}$ & $582,17^{\mathrm{b}}$ & $576,33^{\mathrm{b}}$ \\
\hline & 2 & $805,09^{\mathrm{c}}$ & $602,50^{\mathrm{b}}$ & $427,50^{\mathrm{a}}$ \\
\hline & 3 & $2.187,28^{\mathrm{f}}$ & $1.898,33^{\mathrm{d}}$ & $2.082,67^{\mathrm{e}}$ \\
\hline & Rerata $(\text { average })^{\text {ns }}$ & $1.193,77$ & $1.027,66$ & $1.028,83$ \\
\hline
\end{tabular}

Fase 1: 1-21 hari, fase 2: 22-28 hari, dan fase 3: 29-42 hari (phase 1: 1-21 days, phase 2: 22-28 days, and phase 3: 29-42 days).

2 K: kontrol (control), DJ: dedak jagung (corn bran), P: pollard.

a,b,c,d,e,f Superskrip yang berbeda pada kolom dan baris yang sama menunjukkan berbeda nyata $(\mathrm{P}<0,05)$

(different superscripts at the same column and row indicate significant differences $(P<0.05)$ ).

ns berbeda tidak nyata (non significant).

Tabel 3. Konsumsi pakan ayam perlakuan pakan dan fase yang berbeda (g/ekor) (feed consumption of chicken with different feed and phase treatment ( $\mathrm{g} / \mathrm{head})$ )

\begin{tabular}{|c|c|c|c|}
\hline \multirow{2}{*}{ Fase $(\text { phase })^{1}$} & \multicolumn{3}{|c|}{ Pakan $(\text { feed })^{2}$} \\
\hline & $\mathrm{K}$ & DJ & $\mathrm{P}$ \\
\hline 1 & $579,39^{b}$ & $571,62^{b}$ & $577,08^{b}$ \\
\hline 2 & $828,84^{\mathrm{d}}$ & $609,61^{\mathrm{c}}$ & $437,50^{\mathrm{a}}$ \\
\hline 3 & $2.132,91^{\mathrm{f}}$ & $1.973,29^{\mathrm{d}}$ & $2.089,60^{\mathrm{e}}$ \\
\hline Rerata (average) & $1.180,54^{\mathrm{z}}$ & $1.051,51^{\mathrm{y}}$ & $1.034,72^{\mathrm{x}}$ \\
\hline
\end{tabular}

Fase 1: 1-21 hari, fase 2: 22-28 hari, dan fase 3: 29-42 hari (phase 1: 1-21 days, phase 2: 22-28 days, and phase 3: 29-42 days).

2 K: kontrol (control), DJ: dedak jagung (corn bran), P: pollard.

a,b,c,d,e,f Superskrip yang berbeda pada kolom yang sama menunjukkan perbedaan yang nyata $(\mathrm{P}<0,05)$

(different superscripts at the same column indicate significant differences $(P<0.05)$ ).

${ }_{\mathrm{x}, \mathrm{y}, \mathrm{z}}$ Superskrip yang berbeda baris yang sama menunjukkan perbedaan yang nyata $(\mathrm{P}<0,05)$ (different superscripts at the same row indicate significant differences $(P<0.05))$.

Table 4. Konsumsi pakan ayam pada jenis kelamin dan fase yang berbeda (g/ekor) (feed consumption of chicken with different sex and phase of treatment (g/head))

\begin{tabular}{|c|c|c|c|}
\hline \multirow{2}{*}{ Fase $(\text { phase })^{1}$} & \multicolumn{2}{|c|}{ Jenis kelamin $(\operatorname{sex})$} & \multirow{2}{*}{ Rerata (average) } \\
\hline & Jantan (male) & Betina (female) & \\
\hline 1 & 569,58 & 582,48 & $576,03^{\mathrm{a}}$ \\
\hline 2 & 638,93 & 611,69 & $625,31^{\mathrm{b}}$ \\
\hline 3 & $2.074,44$ & $2.056,09$ & $2.065,43^{\mathrm{c}}$ \\
\hline Rerata (average) ${ }^{\mathrm{ns}}$ & $1.094,43$ & $1.083,42$ & \\
\hline
\end{tabular}

Fase 1: 1-21 hari, fase 2: 22-28 hari, dan fase 3: 29-42 hari (phase 1: 1-21 days, phase 2: 22-28 days, and phase 3: 29-42 days).

${ }^{\text {a,b,c }}$ Superskrip yang berbeda pada kolom yang sama menunjukkan perbedaan yang nyata $(\mathrm{P}<0,05)$ (different superscripts at the same column indicate significant differences $(P<0.05))$.

ns berbeda tidak nyata (non significant).

yang paling sedikit di antara pakan yang lain mampu mengkonsumsi pakan sama dengan kontrol untuk mengejar ketertinggalannya. Mekanisme pertumbuhan kompensatori adalah kebutuhan hidup pokok yang telah dikurangi dinaikan lagi sehingga terjadi pertumbuhan lagi dengan proporsi lemak dan protein yang berbeda dan untuk meningkatkan efisiensi pakan (Ryan cit. Rincon, 2000).

Interaksi antara perlakuan pakan dan fase menunjukkan perbedaan yang nyata $(\mathrm{P}<0,05)$. Analisis statistik konsumsi pakan pada perlakuan pakan yang berbeda menunjukkan perbedaan yang nyata $(\mathrm{P}<0,05)$. Wahju (1997) menyatakan bahwa, 
banyaknya pakan absolut yang dikonsumsi tergantung pada hewan yang bersangkutan dan tergantung pada besarnya, keaktifannya, temperatur lingkungan dan tujuan dari pemeliharaan.

Analisis statistik perlakuan fase menunjukkan perbedaan yang nyata $(\mathrm{P}<0,05)$ hal ini terjadi karena konsumsi pada tiap fase berubah mengalami kenaikan. Analisis statistik perlakuan jenis kelamin menunjukkan konsumsi pakan jantan dan betina berbeda tidak nyata. Interaksi perlakuan jenis kelamin dan fase menunjukkan perbedaan yang tidak nyata.

\section{Berat badan ayam}

Dari analisis statistik menunjukkan bahwa interaksi perlakuan pakan pengisi $(\mathrm{K}, \mathrm{DJ}, \mathrm{P})$ dan jenis kelamin menunjukkan perbedaan tidak nyata. Hal ini menunjukkan bahwa jenis kelamin jantan dan betina ketika diberi pakan serasi kemudian pengisi dan dilanjutkan pakan serasi kembali mempunyai respon yang sama. Analisis statistik berat badan interaksi perlakuan pakan, jenis kelamin dan fase menunjukkan perbedaan nyata $(\mathrm{P}<0,05)$. Lemak dalam sel tubuh langsung dapat digunakan oleh tubuh apabila ayam kekurangan energi untuk hidup yaitu melalui hidrolisis oleh enzim lipase menjadi gliserol dan asam lemak bebas kemudian gliserol akan dipakai dalam pembentukan glukosa melalui proses glukoneogenesis (Rizal, 2006).

Analisis statistik berat badan interaksi perlakuan pakan dan fase menunjukkan perbedaan yang nyata $(\mathrm{P}<0,05)$. Berat badan bertambah sesuai dengan lamanya pemeliharaan sedangkan pengaruh pakan pengisi DJ mempengaruhi kenaikan berat badan yang kecil dan pada pakan pengisi $\mathrm{P}$ mengakibatkan berat badan turun pada fase tengah. Pada saat laju pertumbuhan cepat atau pada umur 3-5 minggu kebutuhan protein masih tinggi sehingga harus diimbangi dengan protein yang tinggi pula (Suprijatna et al., 2005). Pemberian pakan pengisi berupa bekatul ditambah mineral B12 sehingga

Tabel 5. Berat badan ayam pada umur 22, 29 dan 42 hari (g/ekor) (chicken body weight at 22,29 and 42 days of age (g/head))

\begin{tabular}{|c|c|c|c|c|}
\hline \multirow{2}{*}{ Jenis kelamin $(\operatorname{sex})$} & \multirow{2}{*}{ Fase $(\text { phase })^{1}$} & \multicolumn{3}{|c|}{ Pakan $(\text { feed })^{2}$} \\
\hline & & $\mathrm{K}$ & DJ & $\mathrm{P}$ \\
\hline \multirow{4}{*}{ Jantan (male) } & 1 & $841,40^{c}$ & $862,14^{\mathrm{c}}$ & $849,33^{c}$ \\
\hline & 2 & $1.427,13^{\mathrm{d}}$ & $898,45^{\mathrm{c}}$ & $770,83^{\mathrm{a}}$ \\
\hline & 3 & $2.630,32^{\mathrm{i}}$ & $2.263,11^{\mathrm{g}}$ & $2.064,89^{f}$ \\
\hline & Rerata (average) ${ }^{\mathrm{ns}}$ & $1.632,95$ & $1.341,32$ & $1.228,35$ \\
\hline \multirow{4}{*}{ Betina (female) } & 1 & $837,28^{b}$ & $803,57^{b}$ & $824,60^{b}$ \\
\hline & 2 & $1.368,15^{\mathrm{d}}$ & $856,25^{\mathrm{c}}$ & $771,25^{\mathrm{a}}$ \\
\hline & 3 & $2.394,11^{\mathrm{h}}$ & $2.048,89^{\mathrm{f}}$ & $1.996,56^{\mathrm{e}}$ \\
\hline & Rerata (average) & $1.533,18$ & $1.236,23$ & $1.197,46$ \\
\hline
\end{tabular}

Fase 1: 1-21 hari, fase 2: 22-28 hari, dan fase 3: 29-42 hari (phase 1: 1-21 days, phase 2: 22-28 days, and phase 3: 29-42 days).

2 K: kontrol (control), DJ: dedak jagung (corn bran), P: pollard.

a,b,c,d,e,f,g,h,i Superskrip yang berbeda pada kolom yang sama menunjukkan perbedaan yang nyata $(\mathrm{P}<0,05)$

(different superscripts at the same column indicate significant differences $(P<0.05)$ ).

ns berbeda tidak nyata (non significant).

Tabel 6. Berat badan ayam dengan perlakuan pakan dan fase yang berbeda (g/ekor) (chicken body weight on different feed and phase treatment ( $\mathrm{g} / \mathrm{head})$ )

\begin{tabular}{cccc}
\hline \hline Fase (phase) & \multicolumn{3}{c}{ Pakan $(\text { feed })^{2}$} \\
\cline { 2 - 4 } & $\mathrm{K}$ & $\mathrm{DJ}$ & $\mathrm{P}$ \\
\hline 1 & $839,34^{\mathrm{c}}$ & $832,85^{\mathrm{b}}$ & $836,96^{\mathrm{c}}$ \\
2 & $1.397,64^{\mathrm{d}}$ & $877,35^{\mathrm{c}}$ & $771,04^{\mathrm{a}}$ \\
3 & $2.512,21^{\mathrm{g}}$ & $2.156,00^{\mathrm{f}}$ & $2.030,72^{\mathrm{e}}$ \\
\hline Rerata (average) & $1.583,06^{\mathrm{x}}$ & $1.288,73^{\mathrm{y}}$ & $1.212,91^{\mathrm{z}}$ \\
\hline
\end{tabular}

Fase 1: 1-21 hari, fase 2: 22-28 hari, dan fase 3:29-42 hari (phase 1: 1-21 days, phase 2: 22-28 days, and phase 3: 29-42 days).

2 K: kontrol (control), DJ: dedak jagung (corn bran), P: pollard.

a,b,c,d,e,f,g Superskrip yang berbeda pada kolom yang sama menunjukkan perbedaan yang nyata $(\mathrm{P}<0,05)$ (different superscripts at the same column indicate significant differences $(P<0.05))$.

${ }^{\mathrm{x}, \mathrm{y}, \mathrm{z}}$ Superskrip yang berbeda pada baris yang sama menunjukkan perbedaan yang nyata $(\mathrm{P}<0,05)$ (different superscripts at the same row indicate significant differences $(P<0.05))$. 
Tabel 7. Berat badan ayam pada perlakuan pakan dan jenis kelamin (g/ekor) (chicken body weight on different feed and sex treatment $(\mathrm{g} / \mathrm{head}))$

\begin{tabular}{cccc}
\hline \hline \multirow{2}{*}{ Fase (phase) } & \multicolumn{2}{c}{ Jenis kelamin $($ sex $)$} & \multirow{2}{*}{ Rerata (average) } \\
\cline { 2 - 3 } & Jantan (male) & Betina (female) & \\
\hline 1 & $850,96^{\mathrm{a}}$ & $821,82^{\mathrm{a}}$ & $836,38^{\mathrm{x}}$ \\
3 & $1.032,14^{\mathrm{c}}$ & $998,55^{\mathrm{b}}$ & $1.015,34^{\mathrm{y}}$ \\
3 & $2.319,44^{\mathrm{e}}$ & $2.146,52^{\mathrm{d}}$ & $2.232,97^{\mathrm{z}}$ \\
\hline Rerata (average) & $1.400,84^{\mathrm{p}}$ & $1.322,29^{\mathrm{q}}$ & \\
\hline
\end{tabular}

1 Fase 1: 1-21 hari, fase 2: 22-28 hari, dan fase 3: 29-42 hari (phase 1: 1-21 days, phase 2: 22-28 days, and phase 3: 29-42 days).

a,b,c,d,e Superskrip yang berbeda pada kolom yang sama menunjukkan perbedaan yang nyata $(\mathrm{P}<0,05)($ different superscripts at the same column indicate significant differences $(P<0.05))$.

$\mathrm{x,y,z}$ Superskrip yang berbeda pada kolom yang sama menunjukkan perbedaan yang nyata $(\mathrm{P}<0,05)($ different superscripts at the same column indicate significant differences $(P<0.05))$.

${ }^{\mathrm{p}, \mathrm{q}}$ Superskrip yang berbeda pada baris yang sama menunjukkan perbedaan yang nyata $(P<0,05)($ different superscripts at the same row indicate significant differences $(P<0.05))$.

ayam mengalami defisiensi makro nutrien, PK dan ME akan menghambat pertumbuhan, semakin lama diberi pakan pengisi semakin terhambat pertumbuhannya (Haryadi dan Wihandoyo, 2005).

Analisis statistik berat badan ayam interaksi perlakuan jenis kelamin dan fase menunjukkan perbedaan yang nyata $(\mathrm{P}<0,05)$. Analisis statistik berat badan pada perlakuan jenis kelamin menunjukkan perbedaan yang nyata $(\mathrm{P}<0,05)$. Scanes et al. (2004) menyatakan pada semua unggas, pertambahan bobot badan jantan lebih cepat dibandingkan dengan berat badan betina dan memerlukan pakan yang lebih banyak daripada betina. Ayam broiler jantan biasanya rerata pertumbuhannya lebih cepat dan lebih langsing dibanding ayam broiler betina dan menunjukkan kapasitas yang lebih baik dalam pertumbuhan kompensasi (Plavnik dan Hurwitz, 1991 cit. Rincon, 2000). Analisis berat badan pada perlakuan fase juga menunjukkan perbedaan yang nyata $(\mathrm{P}<0,05)$.

\section{Konversi pakan}

Pengaruh interaksi antara perlakuan pakan, jenis kelamin dan fase juga menujukkan perbedaan yang tidak nyata terhadap konversi pakan. Konversi pakan pada interaksi antara perlakuan pakan dan jenis kelamin menunjukkan perbedaan yang tidak nyata.

Analisis statistik konversi pakan ayam pada perlakuan pakan menunjukkan perbedaan yang nyata $(\mathrm{P}<0,05)$. Kandungan nutrien pakan yang kurang dari kebutuhan pada kelompok pakan $\mathrm{P}$ dan kandungan serat kasar yang tinggi menyebabkan ayam hanya mengkonsumsi sedikit pakan sehingga asupan nutriennya juga sedikit yang menyebabkan pertumbuhan ayam juga terganggu.

Analisis statistik interaksi perlakuan pakan dan fase terhadap konversi pakan juga menunjukkan perbedaan yang nyata $(\mathrm{P}<0,05)$. Osboum dan
Wilson (1960) cit. Haryadi dan Wihandoyo (2005) menyatakan bahwa, keuntungan kompensasi pertumbuhan klasik adalah meningkatkan efisiensi pakan. Haryadi dan Wihandoyo (2005) menyatakan bahwa perlakuan pakan pengisi berupa bekatul selama 7 hari lebih efisien dalam menggunakan pakan $(1,87)$ daripada perlakuan kontrol atau tanpa pakan pengisi $(1,98)$. Analisis statistik konversi pakan pada ayam jantan dan betina menunjukkan perbedaan yang tidak nyata dan interaksi antara perlakuan jenis kelamin dan fase juga berbeda tidak nyata. Hal ini tidak sesuai dengan penelitian Shariatmadari dan Thorshizi (2004) yang menyatakan bahwa, ayam jantan memiliki berat badan yang lebih tinggi dan konversi pakan yang lebih rendah dibandingkan ayam betina $(1,27$ pada jantan dan 1,38 pada betina).

\section{Persen karkas}

Interaksi antara perlakuan pakan, jenis kelamin dan fase juga menujukkan perbedaan yang tidak nyata. Berat karkas terhadap bobot hidup sangat erat hubungannya, yaitu dengan bertambahnya bobot hidup mengakibatkan bertambahnya bobot karkas (Djulardi, 2004).

Persentase karkas ayam pada perlakuan pakan menunjukkan perbedaan yang tidak nyata dan interaksi antara perlakuan pakan dan fase juga menunjukkan perbedaan yang tidak nyata. Hal ini sesuai dengan penelitian yang pernah dilakukan oleh (Rezaei et al., 2006) yaitu pembatasan pakan dengan menggunakan wood charcoal (arang kayu) pada umur 8-14 hari dengan persentase 4 sampai dengan $20 \%$ tidak mempengaruhi persentase karkas yang dihasilkan.

Persentase karkas pada perlakuan jenis kelamin juga menunjukkan perbedaan yang tidak nyata. Hal ini sejalan dengan penelitian Leeson et al. (1991) yang menyatakan bahwa pembatasan 
Tabel 8. Konversi pakan pada ayam umur 22, 29 dan 42 hari (chicken feed conversion of chicken at 22,29 and 42 days of age)

\begin{tabular}{|c|c|c|c|c|}
\hline \multirow{2}{*}{ Jenis kelamin $(\operatorname{sex})$} & \multirow{2}{*}{ Fase $(\text { phase })^{1}$} & \multicolumn{3}{|c|}{ Pakan $(\text { feed })^{2, \mathrm{~ns}}$} \\
\hline & & $\mathrm{K}$ & DJ & $P$ \\
\hline \multirow{4}{*}{ Jantan (male) } & 1 & 1,29 & 1,23 & 1,28 \\
\hline & 2 & 1,45 & 20,99 & $-5,89$ \\
\hline & 3 & 2,15 & 1,75 & 1,77 \\
\hline & Rerata (average) ${ }^{\mathrm{ns}}$ & 1,63 & 7,99 & $-0,94$ \\
\hline \multirow{4}{*}{ Betina (female) } & 1 & 1,29 & 1,44 & 1,40 \\
\hline & 2 & 1,52 & 12,41 & $-11,95$ \\
\hline & 3 & 2,30 & 1,88 & 2,00 \\
\hline & Rerata (average) & 1,70 & 5,24 & $-2,84$ \\
\hline
\end{tabular}

Fase 1: 1-21 hari, fase 2: 22-28 hari, dan fase 3: 29-42 hari (phase 1: 1-21 days, phase 2: 22-28 days, and phase 3: 29-42 days).

2 K: kontrol (control), DJ: dedak jagung (corn bran), P: pollard.

ns berbeda tidak nyata (non significant).

Tabel 9. Konversi pakan pada ayam dengan perlakuan pakan dan fase (feed conversion of chicken with feed and phase treatment)

\begin{tabular}{cccc}
\hline \hline Fase (phase) & \multicolumn{3}{c}{ Pakan $(\text { feed })^{2}$} \\
\cline { 2 - 4 } & $\mathrm{K}$ & $\mathrm{DJ}$ & $\mathrm{P}$ \\
\hline 1 & $1,29^{\mathrm{b}}$ & $1,34^{\mathrm{b}}$ & $1,34^{\mathrm{b}}$ \\
3 & $1,48^{\mathrm{b}}$ & $16,70^{\mathrm{c}}$ & $-8,92^{\mathrm{a}}$ \\
\hline Rerata (average) & $2,23^{\mathrm{b}}$ & $1,82^{\mathrm{b}}$ & $1,88^{\mathrm{b}}$ \\
\hline & $1,67^{\mathrm{y}}$ & $6,62^{\mathrm{z}}$ & $-1,89^{\mathrm{x}}$ \\
\hline
\end{tabular}

Fase 1: 1-21 hari, fase 2: 22-28 hari, dan fase 3: 29-42 hari (phase 1: 1-21 days, phase 2: 22-28 days, and phase 3: 29-42 days).

2 K: kontrol (control), DJ: dedak jagung (corn bran), P: pollard.

${ }^{\mathrm{a}, \mathrm{b}, \mathrm{c}}$ Superskrip yang berbeda pada kolom yang sama menunjukkan perbedaan yang nyata $(\mathrm{P}<0,05)($ different superscripts at the same column indicate significant differences $(P<0.05))$.

${ }^{\mathrm{x}, \mathrm{y}, \mathrm{z}}$ Superskrip yang berbeda pada baris yang sama menunjukkan perbedaan yang nyata $(\mathrm{P}<0,05)($ different superscripts at the same row indicate significant differences $(P<0.05))$.

Tabel 10. Konversi pakan pada ayam dengan perlakuan jenis kelamin dan fase (feed conversion of chicken with sex and phase treatment)

\begin{tabular}{cccc}
\hline \hline \multirow{2}{*}{ Fase $(\text { phase })^{1}$} & \multicolumn{2}{c}{${\text { Jenis kelamin }(\text { sex })^{\text {ns }}}^{*}$ Rerata (average) } \\
\cline { 2 - 3 } & Jantan $($ male $)$ & Betina (female $)$ & \\
\hline 1 & 1,27 & 1,38 & 1,32 \\
3 & 5,51 & 0,66 & 3,09 \\
\hline Rerata (average) & 1,89 & 2,06 & 1,97 \\
\hline
\end{tabular}

I Fase 1: 1-21 hari, fase 2: 22-28 hari, dan fase 3: 29-42 hari (phase 1: 1-21 days, phase 2: 22-28 days, and phase 3: $29-42$ days).

ns berbeda tidak nyata (non significant).

pakan dengan menggunakan sekam padi $55 \%$ pada umur 4-11 hari pada ayam betina persentase karkasnya $69,13 \%$ berbeda tidak nyata dengan ayam jantan $68,16 \%$. Pada perlakuan fase menunjukkan perbedaan yang nyata $(\mathrm{P}<0,05)$. Hal ini menunjukkan bahwa ayam akan terus mengalami pertumbuhan dan semakin bertambah umurnya maka berat badan meningkat dan persentase karkas juga meningkat.

\section{Persen lemak perut}

Hasil analisis statistik menunjukkan bahwa persen lemak perut pada interaksi perlakuan pakan dan jenis kelamin menunjukkan perbedaan yang tidak nyata. Hal ini menunjukkan bahwa respon ayam jantan dan betina terhadap pakan yang diberikan dari fase awal tengah dan akhir adalah sama. Interaksi antara perlakuan pakan, jenis kelamin dan fase juga menunjukkan perbedaan yang tidak nyata. 
Tabel 11. Persentase karkas pada umur 22, 29 dan 42 hari (\%) (percentage of carcass at 22, 29 and 42 days of ages (\%))

\begin{tabular}{|c|c|c|c|c|}
\hline \multirow{2}{*}{ Jenis kelamin $(\operatorname{sex})$} & \multirow{2}{*}{ Fase $(\text { phase })^{1}$} & \multicolumn{3}{|c|}{ Pakan $(f e e d)^{2, \text { ns }}$} \\
\hline & & $\mathrm{K}$ & DJ & $P$ \\
\hline \multirow{4}{*}{ Jantan (male) } & 1 & 62,18 & 63,92 & 63,77 \\
\hline & 2 & 63,99 & 62,14 & 62,71 \\
\hline & 3 & 68,67 & 64,85 & 66,95 \\
\hline & Rerata (average) ${ }^{\text {ns }}$ & 64,94 & 63,63 & 64,47 \\
\hline \multirow{4}{*}{ Betina (female) } & 1 & 63,82 & 60,99 & 62,67 \\
\hline & 2 & 64,64 & 61,10 & 63,86 \\
\hline & 3 & 69,68 & 65,65 & 66,41 \\
\hline & Rerata (average) ${ }^{\mathrm{ns}}$ & 66,11 & 61,58 & 64,31 \\
\hline
\end{tabular}

Fase 1: 1-21 hari, fase 2: 22-28 hari, dan fase 3: 29-42 hari (phase 1: 1-21 days, phase 2: 22-28 days, and phase 3: 29-42 days).

2 K: kontrol (control), DJ: dedak jagung (corn bran), P: pollard.

ns berbeda tidak nyata (non significant).

Tabel 12. Persentase karkas ayam pada perlakuan pakan dan fase (\%) (percentage of chicken carcass in feed and phase treatment (\%))

\begin{tabular}{cccc}
\hline \hline \multirow{2}{*}{ Fase $(\text { phase })^{1}$} & \multicolumn{3}{c}{ Pakan $(\text { feed })^{2, \text { ns }}$} \\
\cline { 2 - 4 } & $\mathrm{K}$ & $\mathrm{DJ}$ & $\mathrm{P}$ \\
\hline 1 & 63,01 & 62,45 & 63,22 \\
3 & 64,32 & 61,62 & 63,28 \\
\hline Rerata $_{\text {average }}{ }^{\mathrm{ns}}$ & 69,26 & 65,25 & 66,68 \\
\hline
\end{tabular}

Fase 1: 1-21 hari, fase 2: 22-28 hari, dan fase 3: 29-42 hari (phase 1: 1-21 days, phase 2: 22-28 days, and phase 3: 29-42 days).

2 K: kontrol (control), DJ: dedak jagung (corn bran), P: pollard.

ns berbeda tidak nyata (non significant).

Tabel 13. Persentase karkas ayam pada perlakuan jenis kelamin dan fase (\%) (percentage of chicken carcass in sex and phase treatment (\%))

\begin{tabular}{cccc}
\hline \hline \multirow{2}{*}{ Fase (phase) } & \multicolumn{3}{c}{${\text { Jenis kelamin }(\text { sex })^{\text {ns }}}^{1}$} \\
\cline { 2 - 4 } & Jantan (male) & Betina (female) & Rerata $(\text { average })^{\text {a }}$ \\
2 & 63,29 & 62,49 & $62,89^{\mathrm{a}}$ \\
3 & 62,94 & 63,20 & $62,57^{\mathrm{a}}$ \\
\hline Rerata (average) & 66,82 & 67,31 & $67,04^{\mathrm{b}}$ \\
\hline
\end{tabular}

Fase 1: 1-21 hari, fase 2: 22-28 hari, dan fase 3: 29-42 hari (phase 1: 1-21 days, phase 2: 22-28 days, and phase 3: 29-42 days).

${ }^{\mathrm{a}, \mathrm{b}}$ Superskrip yang berbeda pada kolom yang sama menunjukkan perbedaan yang nyata $(\mathrm{P}<0,05)($ different superscripts at the same column indicate significant differences $(P<0.05))$.

ns berbeda tidak nyata (non significant).

Lemak perut merupakan deposisi dari kelebihan metabolisme lemak yang merupakan cadangan energi bagi ayam yang diperoleh dari diet yaitu lemak pakan dan lipogenesis (Ullrey dan Stowe, 1986 cit. Wahyono et al., 2002).

Analisis statistik persentase lemak perut pada perlakuan pakan menunjukkan perbedaan yang nyata $(\mathrm{P}<0,05)$ yaitu pakan $\mathrm{K}$ dan $\mathrm{DJ}$ memiliki persentase lemak perut yang sama sedangkan pada pakan $\mathrm{P}$ berbeda dan memiliki persentase lemak perut paling rendah. Analisis statistik persentase lemak perut pada interaksi perlakuan pakan dan fase menunjukkan perbedaan yang nyata $(\mathrm{P}<0,05)$. Pada fase awal pakan $\mathrm{K}$, DJ, dan $\mathrm{P}$ menunjukkan nilai yang sama karena memang pakan yang diberikan masih sama. Pada fase tengah pakan yang diberikan berbeda sehingga lemak perut berbeda. Pada fase akhir mengalami kenaikan yang nyata $(\mathrm{P}<0,05)$ pada pakan K dan $\mathrm{P}$, sedangkan pakan DJ kenaikannya berbeda tidak nyata dengan nilai tertinggi pada pakan DJ dan terendah pada pakan P. Persentase lemak perut perlakuan pakan $\mathrm{P}$ paling rendah ber- 
beda nyata $(\mathrm{P}<0,05)$ dengan perlakuan $\mathrm{DJ}$ dan pakan K. Leibetseder (1995) cit. Supadmo (1997) menyatakan bahwa lemak abdomen lebih dipengaruhi oleh penambahan lemak pada pakan. Kandungan protein pada dedak jagung juga paling rendah di bandingkan yang lainnya sehingga lemak perut tinggi. Hal ini sejalan dengan pendapat Decuypere et al., 1992 cit. Daghir, 1998 bahwa penambahan sedikit protein pakan akan meningkatkan pertumbuhan, efisiensi pakan dan lemak perut.

Analisis statistik persentase lemak perut pada perlakuan jenis kelamin menunjukkan perbedaan yang nyata $(\mathrm{P}<0,05)$ (Tabel 16) yaitu persentase lemak perut ayam betina lebih tinggi daripada ayam jantan karena ayam betina mempunyai kemampuan yang lebih dalam mendeposit lemak daripada ayam jantan.

Supadmo (1997) menyatakan bahwa pada pakan normal sesuai kebutuhan persentase lemak perut ayam jantan adalah $2,74 \%$ dan ayam betina 2,98\% pada umur 7 minggu. Analisis statistik lemak perut pada perlakuan fase menunjukkan perbedaan yang nyata $(\mathrm{P}<0,05)$ yaitu pada fase awal dan tengah adalah sama kemudian fase akhir berbeda dan paling tinggi. Pada fase akhir pakan yang dikonsumsi lebih banyak di deposit menjadi lemak karena proses pertumbuhan daging sudah berhenti. Seperti yang dilaporkan oleh Rezaei et al. (2006) bahwa, pada umur 6 minggu lemak perut bisa mencapai $2,79 \%$ dan pada umur 7 minggu persentase lemak perut sudah mencapai 3,6\% (Hunton, 1995).

\section{Kandungan lemak daging}

Analisis statistik kandungan lemak daging ayam pada interaksi perlakuan pakan dan jenis kelamin menunjukkan perbedaan yang tidak nyata. Analisis statistik kandungan lemak daging ayam pada interaksi perlakuan pakan, jenis kelamin, dan fase menunjukkan perbedaan yang tidak nyata. Santoso (2000) yang menyatakan bahwa pembatasan pakan pada awal pertumbuhan selama 5,10 dan 15 hari dengan pemberian pakan $75 \%$ dari

Tabel 14. Persen lemak perut ayam pada umur 22, 29 dan 42 hari (\%) (percentage of chicken abdominal fat at 22,29 and 42 days of ages (\%))

\begin{tabular}{lcccc}
\hline \hline \multirow{2}{*}{ Jenis kelamin (sex) } & \multirow{2}{*}{${\text { Fase }(\text { phase })^{1}}^{*}$} & $\mathrm{~K}$ & $\mathrm{Pakan}(\text { feed })^{2, \text { ns }}$ \\
\cline { 3 - 5 } Jantan (male) & 1 & 1,31 & 1,31 & $\mathrm{P}$ \\
& 2 & 1,47 & 1,91 & 0,54 \\
& 3 & 1,78 & 2,48 & 1,12 \\
\hline \multirow{3}{*}{ Betina (female) } & Rerata (average) $^{\text {ns }}$ & 1,52 & 1,94 & 1,00 \\
& 1 & 1,74 & 1,63 & 1,48 \\
& 2 & 2,00 & 2,62 & 0,91 \\
& 3 & 2,60 & 2,69 & 2,39 \\
\hline
\end{tabular}

Fase 1: 1-21 hari, fase 2: 22-28 hari, dan fase 3: 29-42 hari (phase 1: 1-21 days, phase 2: 22-28 days, and phase 3: 29-42 days).

2 K: kontrol (control), DJ: dedak jagung (corn bran), P: pollard.

ns berbeda tidak nyata (non significant).

Tabel 15. Persentase lemak perut ayam perlakuan pakan dan fase (\%) (percentage of chicken abdominal fat at feed and phase treatment (\%))

\begin{tabular}{cccc}
\hline \hline Fase $(\text { phase })^{1}$ & \multicolumn{3}{c}{ Pakan (feed) $)^{2, \text { ns }}$} \\
\cline { 2 - 4 } & $\mathrm{K}$ & $\mathrm{DJ}$ & $\mathrm{P}$ \\
\hline 1 & $1,52^{\mathrm{b}}$ & $1,47^{\mathrm{b}}$ & $1,41^{\mathrm{b}}$ \\
3 & $1,73^{\mathrm{c}}$ & $2,27^{\mathrm{e}}$ & $0,72^{\mathrm{a}}$ \\
\hline Rerata (average) & $2,19^{\mathrm{d}}$ & $2,59^{\mathrm{e}}$ & $1,75^{\mathrm{c}}$ \\
\hline & $1,80^{\mathrm{z}}$ & $2,03^{\mathrm{z}}$ & $1,29^{\mathrm{y}}$ \\
\hline
\end{tabular}

Fase 1: 1-21 hari, fase 2: 22-28 hari, dan fase 3:29-42 hari (phase 1: 1-21 days, phase 2: 22-28 days, and phase 3: 29-42 days).

2 K: kontrol (control), DJ: dedak jagung (corn bran), P: pollard.

a,b,c,d,e Superskrip yang berbeda pada kolom yang sama menunjukkan perbedaan yang nyata $(\mathrm{P}<0,05)($ different superscripts at the same column indicate significant differences $(P<0.05)$.

${ }^{\mathrm{y}, \mathrm{z}}$ Superskrip yang berbeda pada baris yang sama menunjukkan perbedaan yang nyata $(\mathrm{P}<0,05)$ (different superscripts at the same row indicate significant differences $(P<0.05))$.

$n s$ berbeda tidak nyata (non significant). 
Tabel 16. Persentase lemak perut ayam perlakuan jenis kelamin dan fase (\%) (percentage of chicken abdominal fat in sex and phase treatment (\%))

\begin{tabular}{cccc}
\hline \hline \multirow{2}{*}{ Fase $(\text { phase })^{1}$} & \multicolumn{2}{c}{ Jenis kelamin $(\text { sex })^{\mathrm{n} s}$} & \multirow{2}{*}{ Rerata (average) } \\
\cline { 2 - 3 } & Jantan $($ male $)$ & Betina $($ female $)$ & \\
\hline 1 & 1,32 & 1,62 & $1,47^{\mathrm{x}}$ \\
2 & 1,31 & 1,84 & $1,47^{\mathrm{x}}$ \\
3 & 1,79 & 2,56 & $2,18^{\mathrm{y}}$ \\
\hline Rerata (average) & $1,49^{\mathrm{a}}$ & $1,93^{\mathrm{b}}$ & \\
\hline
\end{tabular}

Fase 1: 1-21 hari, fase 2: 22-28 hari, dan fase 3: 29-42 hari (phase 1: 1-21 days, phase 2: 22-28 days, and phase 3: 29-42 days).

${ }^{\mathrm{a}, \mathrm{b}}$ Superskrip berbeda pada baris yang sama menunjukkan perbedaan yang nyata $(\mathrm{P}<0,05)($ different superscripts at the same row indicate significant differences $(P<0.05)$.

${ }^{\mathrm{x}, \mathrm{y}}$ Superskrip berbeda pada kolom yang sama menunjukkan perbedaan yang nyata $(\mathrm{P}<0,05)($ different superscripts at the same column indicate significant differences $(P<0.05)$.

ns berbeda tidak nyata (non significant).

Tabel 17. Kandungan lemak daging ayam pada umur 22, 29 dan 42 hari (\%) (fat content of chicken meat at 22,29 and 42 days of ages (\%))

\begin{tabular}{|c|c|c|c|c|}
\hline \multirow{2}{*}{ Jenis kelamin $(\operatorname{sex})$} & \multirow{2}{*}{ Fase $(\text { phase })^{1}$} & \multicolumn{3}{|c|}{ Pakan $(f e e d)^{2, \text { ns }}$} \\
\hline & & $\mathrm{K}$ & DJ & $\mathrm{P}$ \\
\hline \multirow{4}{*}{ Jantan (male) } & 1 & 0,46 & 0,49 & 0,58 \\
\hline & 2 & 1,21 & 0,93 & 0,96 \\
\hline & 3 & 0,73 & 0,93 & 0,72 \\
\hline & Rerata (average) ${ }^{\mathrm{ns}}$ & 0,80 & 0,78 & 0,75 \\
\hline \multirow{4}{*}{ Betina (female) } & 1 & 0,59 & 0,96 & 0,30 \\
\hline & 2 & 1,06 & 0,71 & 0,62 \\
\hline & 3 & 0,86 & 0,57 & 0,66 \\
\hline & Rerata (average) ${ }^{\mathrm{ns}}$ & 0,84 & 0,75 & 0,53 \\
\hline
\end{tabular}

Fase 1: 1-21 hari, fase 2: 22-28 hari, dan fase 3: 29-42 hari (phase 1: 1-21 days, phase 2: 22-28 days, and phase 3: 29-42 days).

2 K: kontrol (control), DJ: dedak jagung (corn bran), P: pollard.

ns berbeda tidak nyata (non significant).

pakan kontrol diperoleh kandungan lemak karkas yang berbeda tidak nyata. Lebih lanjut dijelaskan pada umur 28 hari kandungan lemak daging pada perlakuan kontrol adalah $19,1 \%$ perlakuan 5 hari $19,0 \%$ perlakuan 10 hari $17,7 \%$ dan perlakuan 15 hari $17,9 \%$ (dari berat basah).

Analisis statistik perlakuan pakan menunjukkan perbedaan yang tidak nyata. Interaksi perlakuan pakan dan fase juga menunjukkan perbedaan yang tidak nyata. Pada perlakuan jenis kelamin juga menunjukkan perbedaan yang tidak nyata meskipun persen lemak perut pada umur 42 hari berbeda nyata hal ini juga tidak sejalan dengan penelitian Supadmo (1997) yang menyatakan bahwa, terdapat perbedaan yang nyata kandungan lemak daging umur 7 minggu antara ayam jantan $(2,68 \%)$ dan ayam betina $(2,86 \%)$.

Analisis statistik perlakuan fase menunjukkan perbedaan yang nyata $(\mathrm{P}<0,05)$ terhadap kandungan lemak daging. Lemak daging bertambah dengan bertambahnya umur ayam. Analisis statistik interaksi antara jenis kelamin dan fase menunjukkan perbedaan yang tidak nyata.

\section{Kesimpulan}

Dari penelitian ini dapat disimpulkan bahwa pemberian pakan pengisi dari umur 22 sampai dengan 28 hari mengakibatkan konsumsi pakan dan berat badan lebih rendah dari perlakuan kontrol, sedangkan konversi lebih tinggi. Konsumsi dan berat badan meningkat pada setiap fase sedangkan konversi pakan pada fase tengah paling tinggi. Berat badan jantan lebih tinggi dari betina sedangkan konsumsi dan konversi sama.

Persentase karkas dan lemak daging sama dengan perlakuan kontrol. Persentase karkas meningkat setiap fase, sedangkan lemak perut menurun pada fase tengah dan pada lemak daging tetap. Persentase karkas dan lemak daging pada jenis kelamin adalah sama sedangkan pada persen lemak perut lebih tinggi betina. 
Tabel 18. Kandungan lemak daging ayam perlakuan pakan dan fase (\%) (fat content of chicken meat in feed and phase treatment (\%))

\begin{tabular}{cccc}
\hline \hline \multirow{2}{*}{ Fase $(\text { phase })^{1}$} & \multicolumn{3}{c}{${\text { Pakan (feed })^{2, \text { ns }}}$} \\
\cline { 2 - 4 } & $\mathrm{K}$ & $\mathrm{DJ}$ & 0,44 \\
2 & 0,53 & 0,73 & 0,79 \\
3 & 1,13 & 0,85 & 0,69 \\
\hline Rerata $^{\text {average }}{ }^{\mathrm{ns}}$ & 0,79 & 0,75 & 0,64 \\
\hline
\end{tabular}

Fase 1: 1-21 hari, fase 2: 22-28 hari, dan fase 3: 29-42 hari (phase 1: 1-21 days, phase 2: 22-28 days, and phase 3: 29-42 days).

2 K: kontrol (control), DJ: dedak jagung (corn bran), P: pollard.

ns berbeda tidak nyata (non significant).

Tabel 19. Kandungan lemak daging ayam perlakuan jenis kelamin dan fase (\%) (fat content of chicken meat in sex and phase treatment (\%))

\begin{tabular}{|c|c|c|c|}
\hline \multirow{2}{*}{ Fase (phase) ${ }^{1}$} & \multicolumn{2}{|c|}{ Jenis kelamin $(\operatorname{sex})^{\mathrm{ns}}$} & \multirow{2}{*}{ Rerata (average) } \\
\hline & Jantan (male) & Betina (female) & \\
\hline 1 & 0,51 & 0,62 & $0,56^{\mathrm{a}}$ \\
\hline 2 & 1,03 & 0,79 & $0,91^{\mathrm{b}}$ \\
\hline 3 & 0,79 & 0,69 & $0,74^{\mathrm{b}}$ \\
\hline Rerata (average) & 0,78 & 0,70 & \\
\hline
\end{tabular}

Fase 1: 1-21 hari, fase 2: 22-28 hari, dan fase 3: 29-42 hari (phase 1: 1-21 days, phase 2: 22-28 days, and phase 3: 29-42 days).

${ }^{\mathrm{a}, \mathrm{b}}$ Superskrip berbeda pada kolom yang sama menunjukkan perbedaan yang nyata $(\mathrm{P}<0,05)($ different superscripts at the same column indicate significant differences $(P<0.05))$.

${ }^{n}$ berbeda tidak nyata (non significant).

\section{Daftar Pustaka}

Anonimus. 2004. Pengaruh pemberian jamu ayam terhadap kualitas karkas ayam buras potong. Copyright (C) 2004 Balitbangda Provinsi Sulawesi Selatan - All rights reserved.

Dhagir, N.J. 1998. Poultry Production in Hot Climates. UK University Press. Cambridge.

Djulardi, A. 2004. Respon ayam broiler terhadap penggantian sebagian jagung dengan tepung biji alpukat dalam ransum. Jurnal Ilmiah Ilmu-Ilmu Peternakan 7(1): 18-24.

Haryadi, F.T. dan Wihandoyo. 2005. Studi kelayakan ekonomi dan pemanfaatan pakan pengisi dan phenomena compensatory growth pada peternakan ayam pedaging. Buletin Peternakan 29(1): 26-34.

Hunton, P. 1995. Poultry Production. Elsevier Science B.V. Amsterdam.

Lesson, S., J.D. Summer, and L. Caston. 1991. Diet dilution and compensatory growth in broiler. Poultry Sience 70: 867-873.

NRC. 1994. Nutrient Requirement of Poultry $9^{\text {th }}$ ed. National Academy Press. Washington.

Nuraini, E., Keontjoko, dan Soehardjono. 2002. Pengaruh penggunaan tepung bulu dan pain dalam pakan terhadap penampilan ayam broiler. Biosain 2 (1).
Palupi, R. 2003. Pertumbuhan ayam petelur fase awal dengan pemberian pakan yang mengandung pollard dan penambahan asam amino sintetis. Skripsi. Fakultas Peternakan Universitas Gadjah Mada. Yogyakarta.

Rezaei, M., A. Teimouri, J. Pourreza, H. Sayyahzadeh, and P.W. Waldroup. 2006. Effect of diet dilution in the starter period on performance and carcass characteristics of broiler chicks. Journal Central European Agriculture 7(1): 63-70.

Rincon, M.U. 2000. Mild feed restriction and compensatory growth in the broiler chiken. Tesis. University of Guelph. Ottawa. Canada.

Rizal, Y. 2006. Ilmu Nutrisi Unggas. Andalas University Press. Padang.

Santoso, U. 2000. Penurunan konsentrasi trigliserida darah oleh program pembatasan pakan di awal pertumbuhan pada broiler. Buletin Peternakan 24(2): 57-63.

Scanes, C.G., G. Brant, and M.E. Ensminger. 2004. Poultry Science. $4^{\text {th }}$ ed. Perason Education, Inc., New Jersey.

Shariatmadari, F. and R.V. Thorshizi. 2004. Feed restriction and compensatory growth in chicks: effect of breed, sex, initial body weight and level of feeding. School of Agriculture, Tarbiat Modares University, Tehran, Iran. 
Soeparno. 1994. Ilmu dan Teknologi Daging. Cetakan kedua Gadjah Mada University Press, Yogyakarta.

Steel, R.G.D. and J.H. Torrie. 1993. Prinsip dan Prosedur Statistika. Suatu Pendekatan Biometrik. Penerjemah Sumantri. Penerbit PT. Gramedia Pustaka Sarana, Jakarta.

Sudarmadji, S., B. Haryono, dan Suhardi. 1989. Analisa Bahan Makanan dan Pertanian. Liberty Yogyakarta. Yogyakarta.

Supadmo. 1997. Pengaruh sumber khitin dan precursor karnitin serta minyak ikan lemuru terhadap kadar lemak dan kolesterol serta asam lemak omega -3 ayam broiler. Disertasi Pasca Sarjana Institut Pertanian Bogor.

Suparjo, S. Syarif, dan Raguati. 2003. Pengaruh penggunaan pakan berserat kasar tinggi dalam ransum ayam pedaging terhadap organ dalam. Jurnal Ilmiah Ilmu-ilmu Peternakan 6(1): 42-48.

Suprijatna, E., U. Atmomarsono, dan R. Kartasudjana. 2005. Ilmu Dasar Ternak Unggas. Penebar Swadaya. Jakarta.

Wahju, J. 1997. Ilmu Nutrisi Unggas. Gadjah Mada University Press. Yogyakarta.

Wahyono, F., H. Wuryastuti, dan I. Widiyono. 2002. Pengaruh penambahan probiotik pada pakan tinggi lemak jenuh atau tidak jenuh terhadap konversi pakan, berat karkas dan berat lemak perut ayam broiler. Agrosains 15(2): 297-306.

Zuprizal $\square 2006$. Nutrisi Unggas. Tidak dipublikasikan. Jurusan Nutrisi dan Makanan Ternak. Fakultas Peternakan. Universitas Gadjah Mada. Yogyakarta. 